\title{
Poverty Eradication In Northern Nigeria: An Assessment Of The Impact Of NAPEP activities in Kano Metropolis
}

\author{
Ali Ado Siro ${ }^{1}$ \\ Department of Sociology/Criminology and Security Studies, Federal University Dutse, Ibrahim Aliyu Bye-Pass, \\ P.M.B. 7156, Jigawa State, Nigeria. \\ Currently \\ A PhD fellow at School of Social Sciences, Universiti Sains Malaysia, Penang
}

\begin{abstract}
Poverty has been one of the social problems bedevilling human race in the contemporary times. It is seen as a catastrophe present in almost all developing societies like Nigeria. Various organisations consisting of public and private make substantive moves toward eradicating this inherent social problem in line with the Millennium Development Goals. To attain this, Nigeria introduced National Poverty eradication Programme (NAPEP) in an attempt to reduce poverty among the populace. The main aim of this paper is to assess the impact of NAPEP activities in Kano Metropolis especially among the youth. The sampling techniques used were systematic and purposive. Research tools remained questionnaire and interviews. The result shows that, majority of the beneficiaries in the study area are males and that most of those enrolled in the scheme benefit immensely, although there exist some shortcomings. It is recommended therefore, the population of the teeming youth should be encouraged in partaking in similar programmes introduced by governments or by private organisations. Corruption especially among the government officials should be checkmated. Hence, adequate funds should be injected into the programme to make it a success.
\end{abstract}

Keywords: Poverty Eradication, Northern Nigeria, NAPEP and Kano Metropolis.

\section{Introduction}

Poverty is a serious social problem confronting Nigeria as it does other nations of the world. The high level of poverty in the country, which seems endemic, is becoming worrisome. Using poverty indicators such as literacy level, unemployment, access to safe water, maternal and infant mortality, destitution, and number of people living on less than one dollar a day (International Poverty Line), Nigeria is found to rank among the 25 poorest nations in the world below Kenya, Ghana, and Zambia (World Bank Report, 2002). Abubakar (1975), Hill (1982) and Williams (1984) argued that the main factors associated with poverty in Nigeria are unemployment, illiteracy, poor governance, corruption, high inflation, low income, environmental degradation, use of outdated and inefficient system of agriculture and craft, inadequate infrastructure, lack of credit and marketing facilities, unfavourable rural institutions especially in respect to land tenure, cultural and institutional rigidities, lack of viable non-farm employment opportunities in the rural sector there by leading to over crowding on the land and under utilization of labour, etc.

Nigeria as a country was perceived for many decades as one of the richest nations in Africa because of her great petroleum reserves and large population. Ironically, the most dominant feature of the Nigerian economy is unemployment and poverty. Therefore, there is a need for a development plan that will revitalize the economy for the benefit of many Nigerians thereby providing relevant strategies for combating poverty in the country. The resultant poverty has posed questions about the wisdom of conventional strategies for national development. Relatively, the estimated population of Nigeria in 2002 was 129,934,911, and rose to over 150 million according to population and housing census (NPC 2006). Thus, it seems to be difficult for a significant proportion of such a large population to earn a living by farming in an area of 923,768 square kilometres. Hence, land cultivation is not a viable means of providing economic opportunities for many Nigerians.

As an alternative to dependence on the oil sector of Nigeria to provide $20 \%$ of Gross Domestic Product and about $65 \%$ of budgetary revenues, it would seem logical that cost conscious industries should be developed and located in economically depressed areas of Nigeria to take advantage of low cost labour and land, and as a means of national economic development. The poor people in such areas would then have the opportunity to develop skills that would make them employable by industries, and this would ultimately alleviate poverty in Nigeria. Governmental organizations and businesses in Nigeria are yet to invest in significant amounts in

1 Ali Ado Siro is a Lecturer of Criminology and Security Studies, Federal University Dutse, Jigawa State Nigeria. Currently a PhD student of Criminology, School of Social Sciences, Universiti Sains Malaysia, Pulau Pinang, Penang, Malaysia. 
development of non-petroleum industries in the country, as a strategy for economic development. In addition, a lot of Nigerians lack skills, knowledge, tools, beliefs, and values to seek employment opportunities in nonpetroleum industries. People who lack these values to perform financially rewarded activities are not usually employable. This results in a lack of employment opportunities, as employers tend to locate their businesses where appropriate human resources are available. The vicious cycle of poverty therefore continues unabated.

Provision of employment opportunities to the masses is a means of ensuring participation of citizens in the national development process. Lack of employment opportunities for many Nigerians has resulted in large number of Nigerians living in poverty. In turn, poverty leads to alienation of poor people (who are often rural residents) from political-economic functioning of their society. This cycle is complete when alienation further decreases these citizens interest in developing the skills, knowledge, tools, beliefs, and values to perform financially rewarded activities. In order to eradicate unemployment and poverty in Nigeria, innovative methods need to be used to successfully tackle unemployment and poverty. In Nigeria, tackling unemployment requires development and implementation of programs that will directly benefit the poor, by restructuring sources of Nigeria's gross domestic product to significantly include variety of industries that are labour intensive.

In Nigeria, there have been several attempts by government and non-governmental organisations to reduce the high prevalence of poverty in the country. The measures so far implemented have focused more on growth, basic needs, targets and rural development approaches. According to Garba, (2006) and Ogwumike, (2003) these poverty reduction efforts can be delineated into three broad phases: the pre-SAP Era, the SAP Era and the Post-SAP or Democratic Era. Although previous government's efforts aimed at alleviating poverty in the country did not come under the "poverty reduction" nomenclature or slogan, several institutions have emerged and have been concerned with poverty reduction in various ways. By early 2001, a comprehensive National Poverty Eradication Programme (NAPEP) was fully drawn up by the Federal Government with the prime aim of eradicating core (extreme) poverty in the country by the year 2010. This is in line in line with the United Nations Millennium Development Goals (MDGs) of reducing the proportion of people living in poverty by the year 2015. It is on this premise that this research intends to look at the approach of NAPEP, particularly youth empowerment and social welfare efforts in Kano Metropolis with a view of determining the impact of the scheme on the socio-economic lives of the beneficiaries.

\section{Statement of the Problem}

In Nigeria, every government, whether military or civilian embarks on one form of poverty reduction strategy or the other. What is disturbing, however, is the extent to which these programmes and practices of poverty reduction have impacted the poor. Studies on the subject of poverty and (agencies concerned with its reduction in Nigeria indicate that considerable gap exists between the target objective (reducing poverty) and achievement (Aliyu, 2001; Ajakaiye, 2002). This usually begins with policy development and formulation, identification of scope, mandate and target populace, sourcing and utilisation of resources, implementation and control; to mention but a few. The programme officer of NAPEP, Kano State office revealed that in 2008 only 10 percent of the total target population has been attended to with a total score of 30 percent achievement recorded so far in the state. With these and many other existential realities in the country, one begins to wonder whether this agency charged with the responsibility of alleviating poverty is really functioning. One begins to wonder about the true intent and objectives of this programme aimed at eliminating "core" poverty in the country.

\section{Objective of the study}

The broad objective of the study is to look at those activities of National Poverty Eradication Programme (NAPEP) that relate to youth empowerment and social welfare services in Kano Metropolis with a view to determining their impact on the social and economic lives of the beneficiaries.

\section{Operational definition of Key Concepts}

Poverty: The sociological definition of poverty refers to life environment of low income, inadequate work opportunities, poor housing, poor nutrition, poor sanitary and health conditions, a situation of depressed mental and physical state. It also represents lack of freedom, self-esteem and respected position in the society.

Poor: A poor person is described as one who is undernourished and ageing fast, one without self confidence, looks dirty and lives in filthy environment

Indicators of Poverty: There are social as well as economic indices such as life expectancy, higher illiteracy level, infant and child mortality, inability to access qualitative education, ineffective health care and sanitation, low income level and lack of employment opportunities. Also failure to good housing and safe drinking water, that are used to show the prevalence, incidence and trend of poverty in a country or nation.

Poverty Reduction: Means all formal activities geared towards lowering the rate and prevalence of poverty in a particular environment. 
Poverty Line: Is a measure of poverty estimated on the basis of the level of per capita income or consumption of individuals or house holds within a country. It is also the cut off living standard level below which a person is classified as poor.

Youth: Anybody between the years of early childhood and old age.

Youth Empowerment: Provision of programmes and services, notably, in acquisition of skills and expertise in trades and other viable business undertakings to the youth with a view to making them self employed and reliant.

\section{The Concept of Poverty}

\section{Literature Review}

Commonly defined, poverty is "a state of being in which we are unable to meet our needs" (WATT, 2000:15). Baratz and Grimsby, (1972:14) defined poverty as a "condition involving some deprivation and advance occurrences that are closely (but not necessarily exclusively) associated with inadequate economic resources." A closely related definition is that given by Edozien, (1975) in which he looked at poverty in terms of minimum standards of living. The author employs the use of basic needs indicators such as food, clothing, shelter etc to define the concept. Encyclopaedia Encarta, (2006) defined poverty as a condition of having insufficient resources or income. In its most extreme form, poverty is a lack of basic human needs such as adequate and nutritious food, clothing, housing, clean water, security and health services. CBN employs a broader approach in explaining the concept of poverty which is some what similar to that of Encarta (2006). In its reports, CBN (1999) views poverty as:

A state where an individual is not able to carter adequately for his or her basic needs of food, clothing and shelter; is unable to meet social and economic obligations; lacks gainful employment, skills, assets and self esteem; and has limited access to social and economic infrastructures such as education, health, portable water, and sanitation; and consequently, has limited chance of advancing his or her welfare to the limit of his or her capabilities (CBN, 1999:2).

World Bank, (2000) utilised inductive approach to uncover various dimensions of poverty, such as well being, basic infrastructure, illness and assets. In this context it conceives poverty as:

Lack of what is necessary for material well being especially food, but also housing, land and other assets. In other words, poverty is the lack of multiple resources that leads to hunger and physical deprivations (World Bank, 2000:2)

Aluko, (1975) views poverty as denoting absence or lack of basic necessities of life or lack of command over basic consumption needs such as food, clothing, and shelter. National Poverty Eradication Programme, (2001) defines the concept of poverty as:

A situation in which individual families cannot meet their basic and elementary requirements of human survival in terms of good nutrition, shelter, clothing, energy, transport, health, education and recreation (NAPEP, 2001:1).

\section{Poverty Profile in Nigeria}

Poverty in Nigeria was first measured in 1980 by the Federal Office of Statistics (FOS), when 27.2 percent of the population, or eighteen million $(18,000,000)$ people were classified as poor. Before then however, available statistics showed that in 1960, the poverty level of Nigeria stood at 15 percent of the population. By 1985, the Federal Office of Statistics estimated that about 46 percent of Nigerians lived below poverty level, but it dropped to 43 percent by 1992. This rate surged to 66 percent in a 1996 survey and the total number of poor nearly quadrupled to sixty seven million, (UNDP, 1986). By 1999, estimates put the poverty rate at close to 70 percent. Perhaps, 40 percent of these people are the 'core poor', so impoverished that they cannot meet their basic food needs, and indeed, so stunting rate for young Nigerian children. Our measure of chromic nutritional deprivation and food insecurity stands at 42 percent (UNICEF, 2003).

The phenomenon of poverty appears to be more concentrated in rural than in urban areas of the country. The number of rural poor, according to the 1999 World Bank report is roughly twice that of the urban poor. Of the extremely poor, 85 percent lived in the rural areas and more than two-thirds lived on farms. The distribution of poverty is also inequitable on a geographic basis. Regionally, the north-west geopolitical zone has the largest proportion of its population living in poverty, and three northern geopolitical zones have 65 percent of the nation population but account for only 35 percent gross domestic Product (GDP). The 1997 national consumer survey indicated that the average family expenditure per month for the country was $N 4$, 058.00. Out of the country's six geopolitical zones, the Northwest zone has the least figure of $\$ 2,941$ under which Kano state is included. The Eastern zone had the highest figure of $\$ 5,194.00$, almost double the figure for the Northwest zone. Also, the Northwest zone recorded the lowest figure of household income $(\$ 3,769.00)$ while the highest figure of $\$ 7,213.00$ came from the South-Eastern zone. The level of poverty in the zone is striking indeed. 
It is obvious that the incidence of poverty is quite high in all States. However, about three States (Bauchi, Kwara/Kogi, and Sokoto/Kebbi) were higher than the National figure of 70.6 per cent in 1996. An average of 80.5 percent was recorded for Kwara/Kogi in 1999 while Sokoto/Kebbi recorded 88.6 percent during the same period. Five States recorded higher figures than the National figure in 1996 and 1999 but at lower levels than the three States identified earlier. These are Borno/Yobe (71.9 per cent), Imo/Abia (72.7 per cent), Ogun (72.0 per cent) and Ondo (73.7 percent). Twelve (12) States including the Federal Capital Territory, Abuja recorded lower incidence of poverty compared with the national level. The conclusion here is that incidence of poverty is quite pervasive in Nigeria as there are many States with high incidence of poverty (Akanji, 2000).

\section{NAPEP funding}

NAPEP is funded from contributions given to it by State and Local Governments, the private sector and special deductions from the consolidated fund of the Federal Government. It also gets donations from international donor agencies such as the World Bank, the United Nations Development Programme, the European Union, and the Department of International Development, the Japanese International Co-operation Agency, and the German Technical Assistance, and so on.

\section{Structural Theories of poverty}

Theorists in this tradition look not to the individual as a source of poverty, but the economic, political, and social system which causes people to have limited opportunities and resources with which to achieve income and well being. The $19^{\text {th }}$ century social intellectuals developed a full attack on the individual theory of poverty by exploring how social and economic systems overrode and created individual poverty situations. For example, Marx showed how the economic system of capitalism created the "reserve army of the unemployed" as a conscientious strategy to keep wages low. Later Durkheim showed that even the most personal actions of (suicide) were in fact mediated by social systems. Discrimination was separated from skill in one after another area, defining opportunity as socially mediated. Taken to an extreme, radical thinkers argued that the system was flawed and should be radically transformed.

Much of the literature on poverty now suggests that the economic system is structured in such as way that poor people fall behind regardless of how competent they may be. Marxist specifically notes that poverty and inequality are fundamental components of the capitalist mode of production and that capitalism necessarily produces in egalitarian social structure transferred from one generation to another through the provision of social services and opportunities which surround each individual. This kind of situation results in the reproduction of a hierarchical class structures that are always antagonistic to one another. These class structures according to Marxists can only be changed through class struggle or strife, which will in turn transform the society into an egalitarian and one.

\section{Sample Size and Sampling Techniques}

\section{Research Methodology}

A sample of two hundred and ten (210) respondents were selected for this study, to facilitate easy access to information needed the respondents were broken down into two categories: The beneficiaries and the officials of the programme. In this regard, 200 beneficiaries were drawn from a total list of 3,000 beneficiaries from Kano Metropolis while 10 officials of NAPEP Kano State office were selected from a total list of 45 staff. The 200 beneficiaries comprised of 159 males and 41 females. Also, the officials of NAPEP interviewed comprised of 6 males and 4 females. Because the sampling frame of the beneficiaries and that of the officials were easily obtained from the office of NAPEP, systematic and purposive sampling techniques were used in selecting the 210 respondents respectively. In this regard, the 200 beneficiaries were drawn from a total list of 3,000 beneficiaries using systematic sampling method based on a sampling fraction of $1 / 15$. As for the officials of the NAPEP, Purposive sampling method was used in selecting the ten officials interviewed.

\section{Data Collection Tools}

This consists of questionnaire and interview. These instruments were used to obtain data from the field. The questionnaire comprised of both open and closed-ended questions. The interviews were conducted on the NAPEP officials of Kano state office with the help of interview schedule guide. During the interviews, notes were taken and presented in a form of qualitative data in order to augment the quantitative data obtained. 


\section{Presentation and Discussion of Findings}

Table1: Sex Distribution of the Respondents

\begin{tabular}{|l|c|c|}
\hline Sex & Frequency & Percentage \\
\hline Male & 159 & 79.5 \\
\hline Female & 41 & 20.5 \\
\hline Total & $\mathbf{2 0 0}$ & $\mathbf{1 0 0}$ \\
\hline
\end{tabular}

Table1 above shows that there are more male respondents than female; as 79.5 percent of the respondents are males against the 20.5 percent that are females. This shows that males gain access to social as well as economic opportunities than their female counterparts. This may not be unconnected with cultural/traditional as well as religious inhibitions that make males more visible and mobile and they gain access to a lot of social and economic opportunities than the females.

Table 2: Respondents' Occupation (Before enrolment)

\begin{tabular}{|l|c|c|}
\hline Occupation(Before Enrolment) & Frequency & Percentage \\
\hline Carpentry & 16 & 8.0 \\
\hline Farming & 5 & 2.5 \\
\hline Student & 38 & 19.0 \\
\hline Craftwork & 9 & 4.5 \\
\hline Unemployed & 21 & 10.5 \\
\hline Commercial Motorcyclist & 16 & 8.0 \\
\hline Auto electrician & 31 & 15.5 \\
\hline Panel beating & 15 & 8.5 \\
\hline Tailoring & 12 & 6.0 \\
\hline Knitting & 6 & 3.0 \\
\hline Welding & 13 & 6.5 \\
\hline Cosmetology & 6 & 2.0 \\
\hline Mason & 2 & 1.0 \\
\hline Total & $\mathbf{2 0 0}$ & $\mathbf{1 0 0}$ \\
\hline
\end{tabular}

Responses from table 2 above shows that though there is wide range of trade and skills in which the respondents engaged themselves before being enrolled into the programme, these trades and skills seemed to be an ad hoc and temporal in nature, as majority of the participants are either students, unemployed, commercial motorcyclists, etc. This trend can also be explained that, unemployment thrives more among students; and this is due to the fact that their level of education can not guaranty them stable and more fulfilling jobs.

Table 3: Respondents' Occupation (After enrollment)

\begin{tabular}{|l|c|c|}
\hline Occupation(After Enrollment & Frequency & Percentage \\
\hline Welding & 25 & 12.5 \\
\hline Carpentry & 16 & 8.0 \\
\hline Tailoring & 45 & 22.5 \\
\hline KEKE-NAPEP Operator & 29 & 14.5 \\
\hline Craftwork & 12 & 6.0 \\
\hline Auto Electrician & 21 & 10.5 \\
\hline KEKE-NAPEP Mechanic & 7 & 3.5 \\
\hline Panel Beating & 11 & 5.5 \\
\hline Farming & 4 & 2.0 \\
\hline Plumbing & 4 & 2.0 \\
\hline Cosmetology & 5 & 2.5 \\
\hline Knitting & 7 & 3.5 \\
\hline Auto mechanic & 5 & 2.5 \\
\hline Mason & 4 & 2.0 \\
\hline Videography & 5 & 2.0 \\
\hline Total & $\mathbf{2 0 0}$ & $\mathbf{1 0 0}$ \\
\hline
\end{tabular}

Table 3 above indicates some swap in the respondents' occupation. Here some new trades emerged while many respondents changed occupations and are thus trained in occupation other than their initial one. The table indicates that certain trades like welding, tailoring, KEKE-NAPEP operator, etc attract most of the beneficiaries.

Table 4: Respondents' Level of Monthly Income (Before and After Enrollment)

\begin{tabular}{|l|c|c|c|c|c|}
\hline Income before & Frequency & Percentage & Income after & Frequency & Percentage \\
\hline No response & 5 & 2.5 & N 1000-4500 & 47 & 23.5 \\
\hline N 1000-4500 & 155 & 77.5 & N 4501-9500 & 101 & 50.5 \\
\hline N4501-9500 & 28 & 14.0 & N 9501-14500 & 29 & 14.5 \\
\hline
\end{tabular}


Poverty Eradication In Northern Nigeria: An Assessment Of The Impact Of NAPEP activities in....

\begin{tabular}{|l|c|c|c|c|c|}
\hline $\mathrm{N} 9501-14500$ & 9 & 4.5 & $\mathrm{~N} 14501-19500$ & 13 & 6.5 \\
\hline T14501-19500 & 3 & 1.5 & T 19501-ABOVE & 10 & 5.0 \\
\hline Total & $\mathbf{2 0 0}$ & $\mathbf{1 0 0}$ & Total & $\mathbf{2 0 0}$ & $\mathbf{1 0 0}$ \\
\hline
\end{tabular}

Table 4 above shows that there is an upward movement trend in the respondents' level of income after enrollment compared with that before enrollment. The table indicates that significant portion of the beneficiaries (nearly 75\%) revealed positive improvement in their level of income after being enrolled into the programme.

\section{The Impact of NAPEP on the Socio-Economic Status of the Beneficiaries}

Table 5: Whether placed appropriately on the Job Trained.

\begin{tabular}{|l|l|l|}
\hline Appropriate Placement & Frequency & Percentage \\
\hline Yes & 119 & 59.5 \\
\hline No & 81 & 40.5 \\
\hline Total & $\mathbf{2 0 0}$ & $\mathbf{1 0 0}$ \\
\hline
\end{tabular}

Table 5 above indicates that majority of the respondents (59.5\%) were placed appropriately on the job they were trained for. This means that they were provided with basic working materials on graduation for onward self reliance. The working materials given depend on the skills a beneficiary is trained and placed on. The remaining 81 of the beneficiaries $(40.5 \%)$ disclosed that they were not placed appropriately on the job they were trained for. This means that a lot of them were actually graduated and placed on the job they were trained for but were not given any materials on placement except for promises and assurances given to them by the officials that when such materials are available they would be called upon for collection. Corroborating this double placement, the NAPEP officials interviewed disclosed that it was mere shortage of funds that is largely responsible for this. Since NAPEP activities depend on funding from the three tiers of government and other donor agencies, it disburses anything based on the money available.

Table 6: Impact of the scheme beneficiaries' Socio-Economic status

\begin{tabular}{|l|c|c|}
\hline Benefit & Frequency & Percentage \\
\hline Yes & 191 & 95.5 \\
\hline No & 9 & 4.5 \\
\hline Total & $\mathbf{2 0 0}$ & $\mathbf{1 0 0}$ \\
\hline
\end{tabular}

Table 6 above indicates that $95.5 \%$ of the participants reported that the programme has helped improve their socio-economic status while $4.5 \%$ of the beneficiaries said the programme has not helped improve their socio-economic status. This means that majority of the participants have had positive socio-economic benefits from the scheme. Most of the officials interviewed believed NAPEP has done very good in improving the socioeconomic status of its beneficiaries through the provisions of, or rendering social services as well creating an avenue for economic self sustenance. Their arguments are that, through the provisions of credit facilities, skills acquisition, creation of job opportunities, empowerment etc, it is believed that the socio-economic status of such a beneficiary is improved. So, the extent to which NAPEP helped improved the socio-economic status of its beneficiaries depends on the service provided and the ability of the beneficiaries to utilise such services to the best of use. The programme officer and the monitoring officers disclosed that there are some serious problems in this regard; some of the prominent problems are that some of the beneficiaries do sell the materials given to them on graduation as such; the essence of the scheme is defeated.

Table 7: Types of Socio-Economic Benefit

\begin{tabular}{|l|c|c|}
\hline Types of Benefit & Frequency & Percentage \\
\hline Improve my income & 47 & 23.5 \\
\hline Create job opportunity for me & 65 & 32.5 \\
\hline Improve my social status & 16 & 8.0 \\
\hline Improve my education & 5 & 2.5 \\
\hline All of the above & 58 & 29.0 \\
\hline No response & 9 & 4.5 \\
\hline Total & $\mathbf{2 0 0}$ & $\mathbf{1 0 0}$ \\
\hline
\end{tabular}

Table 7 above, which is a follow up question to table 6 indicates that 23 percent of the beneficiaries reported improvement in level of income, 32.5 percent said the programme helped in creating job opportunity for them, 8.0 percent reported that the programme has helped in raising their social status, 2.5 percent disclosed improvement in their level of education, 29.0 percent reported improvement in all the categories listed above, 
while $4.5 \%$ represents those participants who disclosed that the programme has not made any impact in their socio-economic conditions

\section{Summary}

Globally, the need to reduce the high prevalence of poverty incidence has been one of the key issues to government and other stake holders at various levels. In Nigeria, there have been several strategies and programmes aimed at alleviating poverty in the country. A critical assessment of the programmes so far implemented revealed that the programmes have not yielded the desired positive impact on the poor. To this effect, the present democratic government in 2001 establishes the National Poverty Eradication Programme (NAPEP) to help eradicate poverty in the country by the year 2010. This is in line with the United Nations Millennium Development Goals (MDGs) of reducing the proportion of poverty in the whole world by 2015. As a guide to the research, some key concepts relevant to the study were highlighted. The concept and indicators of poverty were also reviewed as structural theories of poverty served as a guide to the study. The study embarked in assessing the impact of this programme in reducing poverty among the Kano Metropolitan youth. Questionnaires and in-depth interviews were employed to generate the information needed for the study. Two hundred youth and ten NAPEP officials making a total of 210 respondents were selected for the research.

Based on the discussed findings, it was concluded that:

\section{Conclusions}

1. More men participated in the programme than their female counterpart. As a result of which they have a higher number of beneficiaries.

2. Youth participated heavily in the programme as more than $80 \%$ of the beneficiaries are within the age limit of $18-40$ years.

3. People with low level of educational attainment participated more in the programme. That is to say poverty is more associated with lower literacy level in the study area.

4. There exist some improvements in the' income level of the beneficiaries.

5. That NAPEP objective of reducing the proportion of poverty in the study area by the year 2010 is not feasible looking at the achievements and progress so far made.

6. There are many impediments that hinder smooth execution of the programme which consist of unnecessary bureaucracy in handling issues, politics, corruption, lack of prudent management of resources, personalization of public utilities, inadequate funding, and lack of proper identification and targeting the deserved subjects among others.

\section{Recommendations}

On the basis of the research findings, the following recommendations are provided:

1. Youth especially women should be encouraged to participate in the programme if it were to become a success.

2. Corruption, mismanagement and abuse of public utilities should be halted.

3. Adequate infrastructural facilities, especially in the rural areas should be provided.

4. Provision of adequate funds to the programme in the form of credit facility, creation of employment opportunities, training and skills acquisition and trade, etc.

5. There should be standard education in the entire country in both formal and informal sectors.

6. There should be prompt and efficient diversification of the country's economy so that the country's over reliance on oil revenue can be checkmated.

7. Intervention in poverty alleviation should not be given in piecemeal or as an alms or charitable/philanthropic donation by governments.

\section{References}

[1]. Abubakar, Y. (1975): "Rural Poverty: Some Agricultural Issues" in Rural Poverty in Nigeria: (Proceedings of the 1975 Annual Conference of Nigerian Economic Society.

[2]. Adebayo, A.A., (1997): "The Role of NGOs in Poverty Alleviation": Selected Papers for the 1997 Annual Conference of Nigerian Economic Society.

[3]. Ajakaiye, O., (2002): “Appraising Poverty Reduction Strategies in Nigeria” in Poverty Eradication Strategy in Nigeria; Mambayya House, Kano.

[4]. Akanji, O.O., (2000): Incidence of Poverty \& Economic Growth in Nigeria. Monteux 4-8.9.

[5]. Alcock et al, (2000): Introducing Social Policy: Pearson Education Limited, England.

[6]. Aliyu, A., (2001): National Poverty Eradication Programme (NAPEP): Completion, Implementation, Coordination and Monitoring: NAPEP Secretariat, Abuja, April.

[7]. Aliyu, A., (2003): the Role of Local Government Councils in the Effective Implementation of NAPEP. NAPEP Secretariat. 
[8]. Aluko, S.A., (1975): "Poverty: Its Remedies", in the Proceedings of the 1975 Annual conference of the Nigerian Economic Society, Ibadan

[9]. Bratz, C. and Grimsby, E. (1972): Poverty among the urban poor, O and J publications, (1972:4).

[10]. Central Bank of Nigeria, Enugu Zone, (1999): "A Profile of Regional/Zonal Poverty in Nigeria":

In, Measuring and Monitoring Poverty in Nigeria, Proceedings of

[11]. Dranze, J. and Sean, A., (2000): Hunger and Public Action, Oxford: Oxford University Press.

[12]. Edozien, E.O., (1975): "Poverty: Some Issues in Concept and Theory", in Rural Poverty in Nigeria (op.cit.).

[13]. Federal Office of Statistics (1997): National Consumer Survey November 1996/97, Abuja.

[14]. Federal Office of Statistics, (1997): Poverty Profile in Nigeria.

[15]. Garba, A. (2006): "Alleviating Poverty in Nigeria": Paper presented at the Annual Conference of Zumunta Association, U.S.A, Minneapolis, MN.

[16]. Hill, O., (1982): "General Causes of Poverty in Hausa Land" in C. Allen and G. Williams (ed), Sociology and Developing Societies. London: Macmillan.

[17]. NPC (2006): National population and Housing census, March, 2006.

[18]. Obadan, M. I. (1996): "Poverty in Nigeria: Characteristics, Alleviation Strategies and Programmes", NCEMA Analysis Series, Vol. 2, No. 2 ...

[19]. UNICEF (2003): Poor in Focus: A quarterly Journal, September, 2003.

[20]. Watt, P., (2000): Social Investment and Economic Growth: Strategy to Eradicate Poverty. Oxford: Oxfam G.B.

[21]. Webster, A., (1993): Introduction to the Sociology of Development. Hong Kong: The Macmillan Press.

[22]. Williams, F., (1984): Social Policy: A critical Introduction. Cambridge: Policy Press.

[23]. World Bank, (1999): Nigeria: Poverty in the Midst of Plenty. Report No. 120 Washington DC.

\section{Websites visited}

$\mathrm{http} / / \mathrm{www} \cdot$ goals.com

$\mathrm{http} / / \mathrm{www}$.wikipedia.com

$\mathrm{http} / / \mathrm{www}$.antislaverysociety.com

$\mathrm{http} / / \mathrm{www} . \mathrm{msn} . \mathrm{com}$

$\mathrm{http} / / \mathrm{www}$. encyclopedia.com

$\mathrm{http} / / \mathrm{www}$.encarta.com

$\mathrm{http} / /$ www.undp.org 